\title{
Pengaruh Kinerja Keuangan dan Penerapan GCG terhadap Potensi Kebangkrutan pada PT Bank Muamalat Indonesia Tbk
}

\author{
The effects of financial performanceand the implementation of GCG on financial distress PT \\ Bank Muamalat Indonesia Tbk
}

\section{Jihan Humaira}

Program Studi D4 Keuangan Syariah, Politeknik Negeri Bandung

E-mail: humairajihan@gmail.com

\section{Benny Barnas}

JurusanAkuntansi, Politeknik Negeri Bandung

E-mail: benny.barnas@gmail.com

\section{Kristianingsih}

JurusanAkuntansi, Politeknik Negeri Bandung

E-mail: kristianingsih@polban.ac.id

\begin{abstract}
This study aims to determine the effect of financial performance as proxied by ROA, BOPO, $C A R$ and FDR as well as the implementation of good corporate governance proxied by the Sharia Supervisory Board on financial distress (Modified Altman Z-Score) at Bank Muamalat 2008-2018. This research method uses a case study method with secondary data in the form of quarterly financial reports and GCG reports issued by PT Bank Muamalat Indonesia Tbk. for the period 2008-2018, data obtained from the Financial Services Authority and other data related to the subject and object of research. This study uses the Multiple Linear Regression method with the help of Software Statistic Eviews 9. From this study, the results show that $\mathrm{RO} A$ has no effecton financial distress, $B O P O$ bas no effect on financial distress, $C A R$ bas a significant positive effect on financial distress, FDR has a significant negative effect on financial distress, and GCG has no effect on financial distress.
\end{abstract}

Keywords: bank Muamalat, finansial performance, financial distress

\section{Pendahuluan}

Industri perbankan syariah telah berkembang pesat di berbagai negara di dunia. Meskipun total asetnya masih sangat kecil jika dibandingkan dengan bank konvensional, perkembangan bank syariah cukup memuaskan, terutama di negara TimurTengah dan Asia Tenggara (Lassoued, 2018). Di Indonesia, selaku negara dengan jumlah penduduk muslim terbanyak di dunia tentunya bank syariah menunjukkan perkembangan yang cukup baik. Namun, bank syariah di Indonesia mempunyai permasalahan yang cukup menjadi perhatian berbagai pihak yaitu terkait market share yang sangat rendah. Market share bank syariah terhadap industri perbankan hanya sebesar $6,01 \%$ per Oktober 2019 (Otoritas Jasa Keuangan, 2019). Hal tersebut sangat disayangkan padahal potensi pertumbuhan bank syariah di Indonesia sangat besar karena mayoritas penduduknya beragama Islam (Huda, 2019). Market share yang rendah akan berdampak terhadap stabilitas bank syariah dan kedepannya dapat menimbulkan berbagai permasalahan, salah satunya masalah kesulitan keuangan atau financialdistress. 


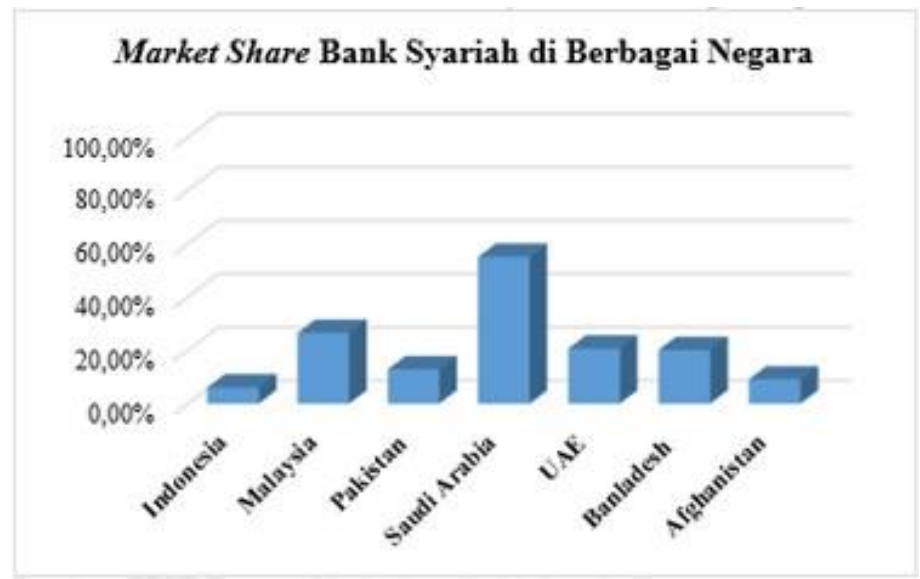

Gambar 1. Market Sbare Bank Syariah di Berbagai Negara Sumber: IFSB Report 2019 (data diolah kembali)

Kemudian, industri perbankan syariah di Indonesia sedang diuji karena Bank Muamalat selaku bank syariah pertama di Indonesia sedang mengalami kesulitan keuangan. Hal tersebut bermula ketika Bank Muamalat mengalami penurunan kinerja keuangan pada tahun 2013. Saat itu Bank Muamalat terbelit persoalan pembiayaan bermasalah (NPF) yang semakin tinggi. Penyebab utamanya adalah karena salah satu debitur yaitu Batavia Air mengalami pailit dan alokasi dana yang macet sebesarRp120miliar. OutstandingpembiayaanBankMuamalatsaat Batavia Air mengalami kepailitan adalah Rp 186 miliar. Akibatnya pendapatan Bank Muamalat menurundrastis dan mengalami kerugian miliaran rupiah (www.voa-islam.com,2015). Peristiwa yang dialami Bank Muamalat ini cukup menjadi perhatian banyak pihak.

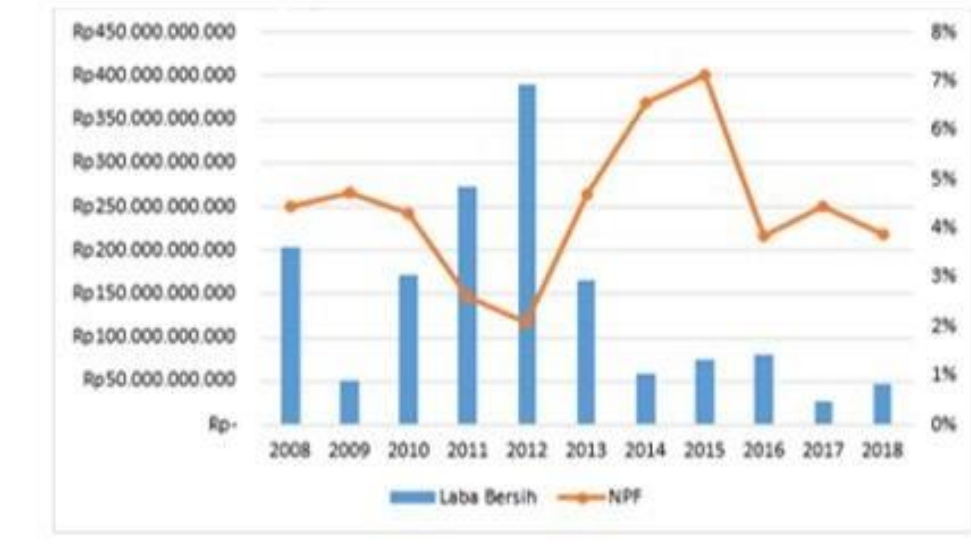

Gambar 2. Perkembangan NPF dan Laba Bersih Bank Muamalat Periode 2008-2018 Sumber: Laporan Keuangan Bank Muamalat (data diolah kembali)

Pada grafik diatas terlihat bahwa kinerja keuangan Bank Muamalat mengalami penurunan. Laba besih pada tahun 2013 menurun drastis karena persoalan pembiayaan bermasalah (NPF) yang tinggi. Lonjakan NPF sampai pada level di atas 5\%, lebih tinggi dari batas maksimal ketentuan Bank Indonesia. Penurunan kinerja keuangan ini perlu diwaspadai karena dapat menimbulkan kondisi kesulitan keuangan bahkan kebangkrutan.

Berdasarkan penjelasan di atas maka penulis ingin melakukan penelitian mengenai faktor apa saja yang mempengaruhi potensi kebangkrutan pada Bank Muamalat dengan menggunakan variabel keuangan dan non-keuangan. Dalam penelitian yang dilakukan pada perusahaan di India menyatakan bahwa variabel keuangan memiliki tingkat akurasi prediksi sebesar 85,19\% sedangkan variabel non-keuangan sebesar 89,81\% (Balasubramanian et al., 2019). Dalam penelitian ini, 
variabel keuangan yang digunakan yaitu Return on Assets (ROA), Beban Operasional Pendapatan Operasional (BOPO), Capital Adequacy Ratio (CAR), dan Financing to Deposits Ratio (FDR). Kemudian, variabel non-keuangan yang digunakan yaitu mekanisme good corporate governance yang diukur melalui keberadaan Dewan Pengawas Syariah (DPS).

Good corporate governance ialah sebuah sistem yang bertujuan untuk mengendalikan dan mengatur perusahaan agar dapat memberikan value added untuk pihak stakeholders. Penerapan good corporate governance dalam perbankan syariah sangat penting karena dapat menumbuhkan kepercayaan masyarakat serta meningkatkan kinerja banksyariah.

Salah satu struktur good corporate governance dalam bank syariah yaitu adanya Dewan Pengawas Syariah (DPS). Dewan Pengawas Syariah memiliki peran sangat penting karena mereka memastikan kegiatan operasional dalam bank syariah tetap berjalan sesuai dengan kaidah Islam. Oleh sebab itu, penulis menggunakan variabel Dewan Pengawas Syariah karena penulis ingin mengetahui bagaimana pengaruh nilai keislaman terhadap potensi kebangkrutan. Nilai-nilai Islam akan berdampak terhadap perilaku seseorang termasuk dalam hal mengambil keputusan, misalnya keputusan manajerial. Jika nilai-nilai Islam dilaksanakan dengan benar, maka diharapkan keputusan manajerial yang dibuat juga akan benar (Reza \& Violita, 2018).

Untuk model prediksi kebangkrutan, penelitian ini menggunakan model Altman Z-Score Modifikasi. Model Altman Z Score Modifikasi adalah suatu perangkat untuk mengukur apakah suatu perusahaan sedang mengalami gejala financial distress yang mengarah pada kebangkrutan atau tidak. Model Altman Z Score Modifikasi dapat diterapkan pada semua jenis perusahaan baik perusahaan manufaktur maupun perusahaan non manufaktur khususnya perusahaan jasa, sehingga model ini cocok diterapkan pada bank syariah (Ramadhani \& Lukviarman, 2009).

Dari fenomena di atas, penulis tertarik melakukan penelitian lebih lanjut dalam Tugas Akhir ini dengan judul "Pengaruh Kinerja Keuangan dan Penerapan Good Corporate Governance Terhadap Potensi Kebangkrutan (Studi Kasus Pada PT Bank Muamalat Indonesia Tbk Periode Tahun 20082018)".

\section{Kajian Pustaka}

\subsection{Financial Distress}

Financial distress ialah peristiwa penurunan kondisi keuangan sebelum kebangkrutan ataupun likuidasi benar-benar terjadi (Plat \& Plat, 2000). Financial distress dapat dijadikan sebagai sinyal atau pertanda potensi kebangkrutan bagi perusahaan, sehingga pihak manajemen perusahaan harus waspada dan hati-hati dalam menghadapi kondisi financial distress agar tidak semakin memburuk (Lestari dkk., 2020).

\subsection{Altman Z-Score Modifikasi}

Terdapat banyak penelitian tentang fenomena kebangkrutan. Salah satunya yaitu Edward I. Altman (1968) melakukan penelitian dengan metode Multiple Discriminant Analysis. Analisis diskriminan ialah sebuah teknik statistik dengan cara mengidentifikasi beberapa jenis rasio keuangan yang diduga mempunyai peran esensial dalam mempengaruhi suatu peristiwa, kemudian dikembangkan dalam sebuah model sehingga dapat ditarik kesimpulan dari suatu peristiwa (Ramadhani \& Lukviarman, 2009).

Dalam penelitiannya mengenai kebangkrutan perusahaan, Altman terus mengembangkan model prediksi dari waktu-waktu sehingga penerapannya tidak terbatas pada perusahaan manufaktur saja tetapi sudah meliputi perusahaan non manufaktur, perusahaan manufaktur non publik, serta perusahaan obligasi korporasi. Perkembangan model Altman terdiri dari Model Altman Pertama (1968), Revisi (1977), dan Modifikasi(1995). 
Pada penelitian ini, penulis memilih Model Altman Modifikasi karena penerapannya cocok untuk perusahaan non manufaktur seperti perbankan. Berikut rumus model Altman modifikasi:

$$
Z=6,56 \times 1+3,26 \times 2+6,72 \times 3+1,05 \times 4
$$

Keterangan:

$\mathrm{X} 1=$ Working Capital $/$ Total Asset

$\mathrm{X} 2=$ Retained Earnings $/$ Total Asset

$\mathrm{X} 3=E B I T /$ Total Asset

$\mathrm{X} 4$ = Book Value of Equity / Book Value of Liabilities

Kriteria perusahaan yang sehat dan bangkrut didasarkan pada nilai $Z$-score model Altman Modifikasi yaitu:

1. Jika nilai indeks $Z<1,1$ maka perusahaan diprediksi bangkrut.

2. Jika nilai indeks $1,1<\mathrm{Z}<2,6$ maka termasuk grey area (perusahaan diprediksi mengalami masalah keuangan dan berpotensi akan bangkrut).

3. Jika nilai indeks $Z>2,6$ maka termasuk perusahaan yang tidak bangkrut.

\subsection{Kinerja Keuangan}

Kinerja keuangan ialah sebuah analisis yang bermaksud untuk melihat kondisi perusahaan apakah sudah melakukan kegiatan usaha secara baik dan benar dengan tetap melaksanakan aturan pelaksanaan keuangan yang telah ditetapkan (Irham, 2011). Melalui penilaian kinerja keuangan maka bisa diketahui kondisi likuiditas, solvabilitas, profitabilitas dan kondisi aktivitas usaha perusahaan yang mana komponen-komponen tersebut sangat penting dalam menilai keberlangsungan suatu bisnis.

Kinerja keuangan bisa dinilai melalui berbagai metode pengukuran. Pada penelitian ini, metode pengukuran kinerja keuangan yang dipilih yaitu metode analisis rasio keuangan. Rasio keuangan yang digunakan diantaranya sebagai berikut.

a. Return on Assets (ROA)

Rasio ini digunakan untuk mengukur kemampuan perusahaan dalam menghasilkan laba selama periode tertentu (Hijriyani \& Setiawan, 2017). Rumus ROA adalah sebagai berikut.

$$
\text { Return on Assets }=\frac{\text { EAT }}{\text { Total Assets }} \times 100 \%
$$

b. Biaya Operasional Pendapatan Operasional (BOPO)

Rasio BOPO digunakan untuk mengukur tingkat efisiensi dan kemampuan bank dalam melakukan kegiatan operasinya (Hijriyani \& Setiawan, 2017). Rumus BOPO adalah sebagai berikut.

$$
\mathrm{BOPO}=\frac{\text { Beban Operasional }}{\text { Pendapatan Operasional }} \times 100 \%
$$


c. Capital Adequacy Ratio (CAR)

Rasio ini menunjukkan kekuatan modal yang dimiliki perusahaan untuk menanggung aktiva yang berisiko. Rumus CAR adalah sebagai berikut.

$\mathrm{CAR}=\frac{\text { Total Modal }}{\text { Aktiva Tertimbang Menurut Risiko }} \times 100 \%$

d. Financing to Deposit Ratio (FDR)

FDR adalah rasio total volume pembiayaan dengan total penerimaan dana. Rumus FDR adalah sebagai berikut.

$$
\text { FDR }=\frac{\text { Total Volume Pembiayaan }}{\text { Total Penerimaan Dana }} \times 100 \%
$$

\subsection{Good Corporate Governance}

Menurut PBI No.11/33/PBI/2009 Tentang Pelaksanaan Good Corporate Governance Bagi Bank Umum Syariah dan Unit Usaha Syariah, Good Corporate Governance ialah sebuah tata kelola Bank dengan menerapkan prinsip keterbukaan, pertanggungjawaban, profesional, akuntabilitas, dan kewajaran.

Mekanisme Good Corporate Governance antara Bank Konvensional dengan Bank Syariah pada dasarnya serupa, tetapi terdapat perbedaan di antara keduanya yaitu adanya sharia compliance yaitu ketaatan terhadap prinsip syariah. Pelaksanaan sharia compliance pada bank syariah yaitu salah satunya melalui Dewan Pengawas Syariah.

Dewan Pengawas Syariah dalam tata kelola bank syariah keberadaannya sejajar dengan komisaris. Bila komisaris berperan sebagai pengawas kinerja direksi, maka DPS berperan sebagai pengawas manajemen bank yang berhubungan dengan kegiatan operasional agar tetap sejalan dengan prinsip syariah.

\section{Metode Penelitian}

Penelitian ini memakai metode studi kasus, yaitu sebuah metode yang secara spesifik mendalami suatu peristiwa yang terjadi dalam situasi kehidupan nyata (Yin, 2014). Penulis merasa metode studi kasus sangat tepat untuk penelitian ini karena penulis ingin mendalami fenomena isu kebangkrutan yang dialami Bank Muamalat.

Jenis penelitian ini adalah penelitian kuantitatif. Alasan penulis menggunakan jenis kuantitatif adalah dengan mempertimbangkan yang dikemukakan oleh Arikunto (2006) tentang sifat umum penelitian kuantitatif, antara lain: (1) kejelasan unsur: tujuan, subjek, sumber data sudah mantap, dan rinci sejak awal, (2) dapat menggunakan sampel, (3) kejelasan desain penelitian, dan (4) analisis data dilakukan setelah semua data terkumpul. Kemudian menurut beberapa ahli, penelitian kuantitatif sangat tepat dalam mengukur hubungan antar variabel dalam sebuah populasi. Melalui pendekatan kuantitatif tersbeut, penulis ingin mengetahui hubungan kausal dimana bertujuan untuk menemukan ada atau tidaknya pengaruh 


\section{Hasil dan Pembahasan}

\subsection{Hasil Analisis Data}

Berdasarkan data sekunder yang diperoleh dan kemudian diolah dalam aplikasi Eviews 9, maka diperoleh hasil regresi linear berganda sebagai berikut:

Tabel 1. Hasil Analisis Data

\begin{tabular}{crrrr}
\hline \hline Variable & Coefficient & Std. Error & t-Statistic & Prob. \\
\hline \hline C & 1.243790 & 0.653488 & 1.903310 & 0.0646 \\
LOG(X1 ROA) & 0.035651 & 0.069192 & 0.515242 & 0.6094 \\
LOG(X2 BOPO) & -0.066253 & 0.987600 & -0.067085 & 0.9469 \\
LOG(X3 CAR) & 0.824224 & 0.240549 & 3.426423 & 0.0015 \\
LOG(X4 FDR) & -2.374326 & 0.383841 & -6.185702 & 0.0000 \\
LOG(X5 GCG) & 0.432190 & 0.493519 & 0.875731 & 0.3867 \\
\hline \hline
\end{tabular}

Sumber: Data sekunder yang diolah, 2020

Berdasarkan tabel di atas, maka diperoleh persamaan regresi sebagai berikut:

$\mathrm{FD}=1,2438+0,0357 \mathrm{ROA}-0,0663 \mathrm{BOPO}+0,8242 \mathrm{CAR}-2,3743 \mathrm{FDR}+0,4322 \mathrm{GCG}$

\subsection{Uji AsumsiKlasik}

\section{Uji Normalitas}

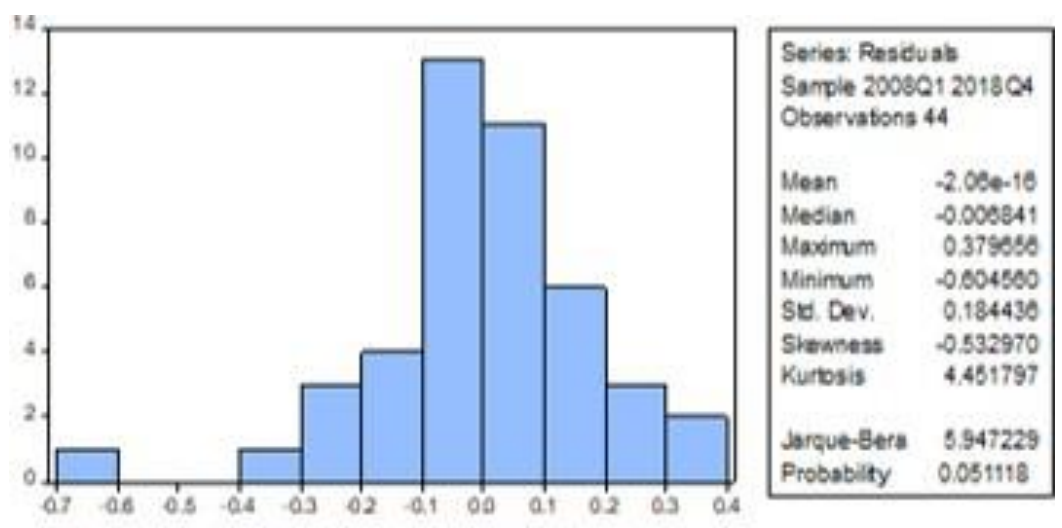

Gambar 3. Grafik Hasil Uji Normalitas

Sumber: Data Sekunder yang diolah, 2020

Berdasarkan hasil pengujian pada gambar di atas menunjukan bahwa data telah terdistribusi secara normal. Hal ini ditunjukan dengan nilai probabilitas Jarque-Bera sebesar 0,051118 yang berada di atas 0,05 . 


\section{Uji Multikolinearitas}

Tabel 2. Hasil Uji Multikolinearitas

\begin{tabular}{cccc}
\hline \hline Variable & $\begin{array}{c}\text { Coefficient } \\
\text { Variance }\end{array}$ & $\begin{array}{c}\text { Uncentered } \\
\text { VIF }\end{array}$ & $\begin{array}{c}\text { Centered } \\
\text { VIF }\end{array}$ \\
\hline C & 0.427046 & 488.1455 & NA \\
LOG(X1_ROA) & 0.004788 & 146.6594 & 6.874589 \\
LOG(X2_BOPO) & 0.975354 & 20.52154 & 7.770957 \\
LOG(X3_CAR) & 0.057864 & 284.4668 & 1.235553 \\
LOG(X4_FDR) & 0.147334 & 2.141474 & 1.316596 \\
LOG(X5_GCG) & 0.243561 & 354.1181 & 1.904245 \\
\hline \hline
\end{tabular}

Sumber: Data sekunder yang diolah, 2020

Berdasarkan hasil pengujian di atas diketahui bahwa nilai VIF variabel ROA sebesar 6,874589, BOPO sebesar 7,770957, CAR sebesar 1,235553, FDR sebesar1,316596 dan GCG sebesar 1,904245. Semua variabel memiliki nilai VIF kurang dari 10,00 sehingga dapat disimpulkan bahwa model regresi tidak mengalami multikolinearitas.

\section{Uji Heteroskedastisitas}

Tabe1 3. Hasil Uji Heteroskedastisitas

Heteroskedasticity Test: Harvey

\begin{tabular}{llll}
\hline \hline F-statistic & 1.214436 & Prob. F(5,38) & 0.3211 \\
Obs*R-squared & 6.062237 & Prob. Chi-Square(5) & 0.3002 \\
Scaled explained SS & 4.612341 & Prob. Chi-Square(5) & 0.4650 \\
\hline \hline
\end{tabular}

Sumber: Data sekunder yang diolah, 2020

Berdasarkan uji Harvey di atas, nilai dari Prob. chisquarepada Obs*R-Squaredsebesar0,3002 yang mana lebih besar dari taraf signifikan $(\alpha=5 \%)$, maka dapat disimpulkan bahwa tidakada masalah heterokedastisitas.

\section{Uji Autokorelasi}

Tabel 4. Hasil Uji Autokorelasi

Breusch-Godfrey Serial Correlation LM Test:

\begin{tabular}{llll}
\hline \hline F-statistic & 1.755314 & Prob. F(2,36) & 0.1873 \\
Obs*R-squared & 3.909522 & Prob. Chi-Square(2) & 0.1416 \\
\hline \hline
\end{tabular}

Sumber: Data sekunder yang diolah, 2020

Berdasarkan hasil uji autokolerasi dengan menggunakan uji LM maka didapat nilai Prob. chi square sebesar 0,1416 yang mana nilai tersebut lebih besar dari taraf signifikan $(\alpha=5 \%)$, sehingga disimpulkan bahwa tidak terdapat autokorelasi.

Maka berdasarkan hasil uji asumsi klasik di atas, dapat disimpulkan bahwa model regresi sudah memenuhi syarat uji asumsi klasik sehingga dapat dilanjutkan untuk melakukan uji hipotesis.

\subsection{Uji AsumsiKlasik}

Uji t

Berdasarkan analisis data pada tabel 1 di atas, dapat diketahui bahwa:

a) Pengujian Hipotesis Pertama

Hipotesis pertama ditolak, karena nilai probabilitas ROA sebesar 0,6094 $>0,05$ serta nilai $\mathrm{t}$ hitung yang lebih kecil dari t tabel $(0,231<1,96)$. Sehingga dapat disimpulkan bahwa ROA tidak 
berpengaruh signifikan terhadap Potensi Kebangkrutan.

b) Pengujian Hipotesis Kedua

Hipotesis kedua ditolak, karena nilai probabilitas BOPO sebesar $0,9469>0,05$ serta nilai $\mathrm{t}$ hitung yang lebih kecil dari t tabel $(0,430<1,96)$. Sehingga dapat disi mpulkan bahwa BOPO tidak berpengaruh signifikan terhadap Potensi Kebangkrutan.

c) Pengujian Hipotesis Ketiga

Hipotesis ketiga diterima, karena nilai probabilitas CAR sebesar $0,0015<0,05$ serta nilai $\mathrm{t}$ hitung yang lebih besar dari t tabel $(9,422>1,96)$. Sehingga dapat disimpulkan bahwa CAR berpengaruh positif signifikan terhadap Potensi Kebangkrutan.

d) Pengujian Hipotesis Keempat

Hipotesis keempat diterima, karena nilai probabilitas FDR sebesar 0,0000 $<0,05$ serta nilai $\mathrm{t}$ hitung yang lebih besar dari $\mathrm{t}$ tabel $(7,147>1,96)$. Sehingga dapatdisi mpulkan bahwa FDR berpengaruh negatif signifikan terhadap Potensi Kebangkrutan.

e) Pengujian Hipotesis Kelima

Hipotesis kelima ditolak, karena nilai probabilitas GCG sebesar 0,3867 >0,05 dengan nilai $\mathrm{t}$ hitung yang lebih besar dari t tabel $(3,104>1,96)$. Sehingga dapatdisi mpulkan bahwa GCG tidak berpengaruh signifikan terhadap Potensi Kebangkrutan.

Uji F

Tabe1 6. Hasil Uji F

\begin{tabular}{lllr}
\hline \hline R-squared & 0.564013 & Mean dependent var & 0.017387 \\
Adjusted R-squared & 0.506646 & S.D. dependent var & 0.279325 \\
S.E. of regression & 0.196196 & Akaike info criterion & -0.293286 \\
Sum squared resid & 1.462722 & Schwarz criterion & -0.049988 \\
Log likelihood & 12.45230 & Hannan-Quinn criter. & -0.203059 \\
F-statistic & 9.831709 & Durbin-Watson stat & 1.468018 \\
Prob(F-statistic) & 0.000004 & & \\
\hline \hline
\end{tabular}

Sumber: Data sekunder yang diolah, 2020

Berdasarkan hasil output uji $\mathrm{F}$ pada tabel di atas menunjukkan bahwa nilai $\mathrm{F}$ hitung sebesar 9,831709 sedangkan nilai $\mathrm{F}$ tabel dengan nilai signifikansi $0.05(5 \%)$ dan df1 $(\mathrm{k}-1)=4$ dan df $2(\mathrm{n}-\mathrm{k})=$ 39 diperoleh nilai $\mathrm{F}$ tabel sebesar 2,456. sehingga dapat dikatakan bahwa $\mathrm{F}$ hitung $>\mathrm{F}$ tabel $(9,831709>2,456)$. Selain itu, terlihat dalam nilai probabilitas Prob(F- statistic) sebesar 0.000004 yang lebih kecil dari nilai signifikansi $0,05(0,000004<0,005)$ maka keputusan yang diambil adalah menerima Ha. Dengan demikian, dapat disimpulkan bahwa ROA, BOPO, CAR, FDR dan GCG secara bersama-sama berpengaruh signifikan terhadap Potensi Kebangkrutan.

\section{Uji Koefisien Determinasi (Uji R2)}

Berdasarkan tabel di atas dapat diketahui besarnya adjusted $R$ square yaitu sebesar 0,506646 atau 50,66\%. Dapat disimpulkan bahwa besar kemungkinan variabel ROA, BOPO, CAR, FDR dan GCG terhadap Potensi Kebangkrutan yang dapat diterangkan oleh model persamaan ini adalah sebesar $50,66 \%$ dan sisanya sebesar $49,34 \%$ dijelaskan oleh variabel yang lain yang tidak terdapat dalam penelitian ini.

\subsection{Hasil Analisis Data}

\section{Pengaruh Return on Assets (ROA) Terhadap Potensi Kebangkrutan}

Hasil uji statistik menunjukkan bahwa ROA tidak berpengaruh terhadap potensi 
kebangkrutan. Return on Assets (ROA) merupakan rasio yang menunjukkan kekuatan bank dalam menghasilkan laba dengan menggunakan aset yang dimiliki secara efektif dan efisien. Dari penjelasan tersebut dapat dikatakan bahwa semakin tinggi ROA maka semakin rendah kemungkinan kebangkrutan terjadi. Namun, kondisi tersebut tidak selalu terjadi seperti itu karena selama bank memiliki kecukupan modal untuk menanggung risiko dan melakukan pengelolaan secara efektif dan efisien terhadap seluruh beban yang dimiliki. Sehingga meskipun kemampuan bank dalam menghasilkan laba menurun, hal tersebut tidak terlalu berdampak terhadap potensi kebangkrutan.

Hasil penelitian ini didukung oleh penelitian Khadapi (2018), Suhadi dan Kusumaningtias (2017), Shidiq dan Wibowo (2017) yang mengatakan ROA tidak berpengaruh signifikan terhadap potensi kebangkrutan. Namun berbeda dengan penelitian Sofiasani dan Gautama (2016), Pratama (2015) yang mengatakan bahwa ROA berpengaruh signifikan terhadap potensikebangkrutan.

\section{Pengaruh Beban Operasional Pendapatan Operasional (BOPO) Terhadap Potensi Kebangkrutan}

Hasil uji statistik menunjukkan bahwa BOPO tidak berpengaruh terhadap potensi kebangkrutan. Hal ini dikarenakan Bank Muamalat cukup efisien dalam mengelola biaya operasionalnya. Nilai rata-rata (mean) BOPO Bank Muamalat selama periode 2008 sampai dengan 2018adalahsebesar90\%.MakaberdasarkandatatersebutdapatdikatakanbahwaBank Muamalat masih memiliki tingkat efisiensi yang cukup baik dikarenakan memiliki nilai BOPO dibawah 93\% (Bank Indonesia,2011), sehingga rasio BOPO tidak terlalu berdampak terhadap potensi kebangkrutan.

Hasil penelitian ini didukung oleh penelitian Erni dan Imron (2018), Pratama (2015), yang mengatakan BOPO tidak berpengaruh signifikan terhadap potensi kebangkrutan. Namun berbeda dengan penelitian Khadapi (2018), Anggraeni dan Amelia (2017), yang mengatakan bahwa BOPO berpengaruh signifikan terhadap potensi kebangkrutan.

\section{Pengaruh Capital Adequacy Ratio (CAR) Terhadap Potensi Kebangkrutan}

Hasil uji statistik menunjukkan bahwa CAR berpengaruh positif sgifin terhadap potensi kebangkrutan. Dengan hubungan yang signifikan tersebut, maka dapat dijelaskan bahwa tingginya rasio ini akan meningkatkan nilai Z-Score sebagai pengukur kondisi kebangkrutan. Tingginya nilai Z-Score menunjukkan semakin stabil kondisi keuangan, sehingga potensi kebangkrutan semakin rendah. Hal ini dikarenakan Bank Muamalat memiliki kekuatan modal yang cukup baik dalam menanggung aktiva yang berisiko. Hal tersebut ditunjukkan melalui nilai rata-rata (mean) rasio CAR Bank Muamalat adalah sebesar 12,74\%, yang mana nilai tersebut sudah memenuhi standar berdasarkan Peraturan BankIndonesia Nomor 15/ 12 /PBI/2013 TentangKewajiban Penyediaan Modal Minimum Bank Umum menyatakan bahwa rasio CAR yang harus dimiliki oleh bank syariah minimal adalah $8 \%$. Semakin tinggi CAR maka semakin tinggijuga modal untuk menanggung aktiva berisiko.

Ketika bank memiliki kecukupan modal yang baik, maka bank akan semakin tahan dalam menghadapi risiko kerugian. CAR yang tinggi pada bank membuat bank mampu membiayai kegiatan operasional bank dan mampu meningkatkan profitabilitas sehingga memperkecil potensi terjadinya kesulitan keuangan. Sehingga apabila bank dalam keadaan merugi (laba negatif) tetapi struktur modalnya bisa dijaga dengan baik, maka CAR akan tetap dalam keadaan tinggi. Oleh karena itu, dengan tingginya rasio ini akan menurunkan potensi kebangkrutan.

Hasil penelitian ini didukung oleh penelitian Khadapi (2018), Afiqoh dan Laila (2018), Syinta (2018), yang mengatakan CAR berpengaruh signifikan terhadap potensi kebangkrutan. Namunberbeda dengan penelitian ErnidanImron (2018), Anggraenidan Amelia (2017), yang mengatakan bahwa CAR berpengaruh signifikan terhadap potensi kebangkrutan. 


\section{Pengaruh Financing to Deposits Ratio (FDR) Terhadap Potensi Kebangkrutan}

Hasil uji statistik menunjukkan bahwa FDR berpengaruh negatif signifikan terhadap potensi kebangkrutan. Dengan hubungan yang signifikan tersebut, maka dapat dijelaskan bahwa tingginya rasio ini akan menurunkan nilai Z-Score sebagai pengukur kondisi kebangkrutan. Rendahnya nilai Z-Score menunjukkan kondisi keuangan yang kurang stabil, sehingga potensi kebangkrutan semakin tinggi. Rasio FDR mencerminkan kondisilikuiditas bank. Semakin tinggi FDR maka semakin rendah kondisi likuiditas bank karena FDR yang tinggi menunjukkan jumlah pembiayaan yang tinggi, sehingga risiko yang dihadapi bank juga semakin tinggi. Penyaluran pembiayaan yang tinggi memang diharapkan bisa menambah pendapatan bagi bank, namun hal tersebut juga meningkatkan risiko pembiayaan bermasalah yang dapat menimbulkan kondisi kesulitan keuangan.

Bank Muamalat memiliki rata-rata FDR yang cukup tinggiyaitu sebesar93\%. Dalamkasus Bank Muamalat banyak terjadi pembiayaan bermasalah yang menimbulkan kerugian pendapatan sehingga meningkatkan risiko kebangkrutan. Oleh karena itu, dengan tingginya rasio ini akan meningkatkan kondisi kesulitan keuangan bahkan kebangkrutan.

Hasil penelitian ini didukung oleh penelitian Khadapi (2018), Afiqoh dan Laila (2018), yang mengatakan FDR berpengaruh signifikan terhadap potensi kebangkrutan. Namun berbeda dengan penelitian Rasyid (2018), Anggraeni dan Amelia (2017), Pratama (2015), yangmengatakan bahwaFDR berpengaruh signifikan terhadap potensikebangkrutan.

\section{Pengaruh GCG (Keberadaan DPD) Terhadap Potensi Kebangkrutan}

Hasil uji statistik menunjukkan bahwa GCG (keberadaan DPS) tidak berpengaruh terhadap potensi kebangkrutan. Dewan Pengawas Syariah (DPS) merupakan suatu badan yang ada di lembaga keuangan syariah dan memiliki independensi yang bertugasdan bertanggungjawab sesuai dengan prinsip-prinsip GCG untuk memberikan nasihat dan saran kepada organ lainnya agar sesuai dengan prinsip syariah, sehingga fokus utama DPS yaitu kepatuhan terhadap prinsip syariah bukan terhadap aspek keuangan. Selain itu, dalam penelitian yang dilakukan oleh Prabowo dan Jamal (2017) telah ditemukan adanya kelemahan peran Dewan Pengawas Syariah yaitu DPS tidak mempunyai kewenangan yang layak sebagai pengawas karena tidak diatur dalam peraturan perundang-undangan. DPS juga tidak mempunyai kewenangan eksekusi secara langsung jika ada temuan pelanggaran syariah. Kewenangan eksekusi hanya dimiliki oleh Bank Indonesia atau Otoritas Jasa Keuangan. Hal ini tentu menghambat proses pengawasan, karena kewenangan yang tidak utuh di tubuh DPS dan DSN (Yudi, 2015).

Hasil penelitian ini didukung oleh penelitian Kartika (2014) dan Sholikati (2018) yang mengatakan bahwa keberadaan DPS tidak berpengaruh signifikan terhadap potensi kebangkrutan. Namun berbeda dengan penelitian Yunesa (2017) dan Yuni (2018) yang mengatakan bahwa DPS berpengaruh signifikan terhadap potensi kebangkrutan.

\section{Penutup}

Berdasarkan hasil penelitian mengenai pengaruh kinerja keuangan dan penerapan good corporate governance terhadap potensi kebangkrutan pada PT Bank Muamalat Indonesia Tbk. periode 2008-2018 maka diperoleh kesimpulan bahwa ROA (Return on Assets) tidak berepengaruh terhadap potensi kebangkrutan, BOPO (Beban Operasional Pendapatan Operasional) tidak berepengaruh terhadap potensi kebangkrutan, CAR (Capital Adequacy Ratio) berpengaruh positif signifikan terhadap potensi kebangkrutan, FDR (Financing to Deposits Ratio) berpengaruh negatif signifikan terhadap potensi kebangkrutan, GCG (keberadaan Dewan Pengawas Syariah) tidak berpengaruh terhadap potensi kebangkrutan.

Penelitian ini hanya difokuskan pada hubungan antara variabel kinerja keuangan dan good corporate governance terhadap potensi kebangkrutan pada PT Bank Muamalat Indonesia Tbk. Oleh karena 
itu, bagi penelitian selanjutnya disarankan untuk menggunakan variabel lain, baik dari variabel keuangan berupa rasio keuangan seperti NPM, ROE, CR dan lainnya, atau variabel non- keuangan seperti keberadaan Dewan Komisaris, Komite Audit, dan lainnya. Faktor makroekonomi seperti inflasi, kurs, dan BI rate juga dapat ditambahkan pada penelitian selanjutnya. Kemudian penelitian selanjutnya juga disarankan untuk menggunakan model prediksi kebangkrutan yang lain seperti model Zmijewski dan model Springate. Selain itu, penelitian selanjutnya diharapkan untuk menambahkan jumlah objek dan periode penelitian karena semakin banyak jumlah periode penelitian maka hasil yang didapat akan sesuai dengan kondisi yang sebenarnya. Penelitian selanjutnya pada topik ini juga dapat dilakukan pada jenis industri lainnya, sehingga hasilnya dapat dibandingkan.

\section{Daftar Pustaka}

Afiqoh, L., \& Laila, N. (2018). Pengaruh Kinerja Keuangan Terhadap Risiko Kebangkrutan Bank Umum Syariah Di Indonesia (Metode Altman Z-Score Modifikasi Periode 2011-2017). Jurnal Ekonomi Dan Bisnis Islam Journal of Islamic Economics and Business), 4(2), 166. https://doi.org/10.20473/jebis.v4i2.10757.

Arikunto, S. (2006). Metode Penelitian Kualitatif. Jakarta: Bumi Aksara

Bank Mumalat Indonesia. (2019). Laporan Pubilkasi Triwulanan dan Laporan GCG Tahunan, http://www.muamalatbank.com, diunduh pada 3 Desember 2019.

Halimatus, S., \& Mauluddi, H. A. (2018). Bank Muamalat Indonesia Profitability Analysis: Study of the Effects of Capital, Asset Quality, Earnings and Liquidity Analisis Profitabilitas Bank Muamalat Indonesia: Studi Pengarub Permodalan, Kualitas Asset, Earnings. 14(1), 69-81.

Hijriyani, N. Z., \& Setiawan, S. (2017). Analisis Profitabilitas Perbankan Syariah di Indonesia sebagai Dampak Dari Efisiensi Operasional. Jurnal Kajian Akuntansi, 1(2), 194-209

Khadapi, Muamar. (2018). Pengaruh CAR, ROA, BOPO, dan FDR Terhadap Financial Distress Bank Umum Syariah di Indonesia Periode 2014-2016.

Kurnia, Y. S. (2018). Pengaruh Good Corporate Governance dan Profitabilitas Terhadap Financial Distress. Skripsi Fakultas Ekonomi Universitas Islam Indonesia.

Ramadhani, A. S., \& Lukviarman, N. (2009). Perbandingan Analisis Prediksi Kebangkrutan Menggunakan Model Altman Pertama, Altman Revisi, dan Altman Modifikasi dengan Ukuran dan Umur Perusahaan Sebagai Variabel Penjelas. Jurnal Siasat Bisnis, 13(1), 15-28.

Shidiq, I., Wibowo B. (2017). Prediksi Financial Distress Bank Umum di Indonesia: Analisis Diskriminan dan Regresi Logistik. Esensi: Jurnal Bisnis dan Manajemen, UI: Jakarta, 7 (1):27- 40.

Sholikati, Putri, Sholahuddin, M. (2018). Analisis Pengaruh RGEC Terhadap Financial Distress Bank Umum Syariah di Indonesia. Skripsi Universitas Muhammadiyah Surakarta.

Sofiasani, G., \& Gautama, B. P. (2016). Pengaruh CAMEL Terhadap Financial Distress Pada Sektor Perbankan Indonesia Periode 2009-2013. Journal of Business Management and Enterpreneurship Education, 1(1), 136-146.

Lestari, H.T, Setiawan, S., \& Afiyanti Tripuspitorini, F. (2020). Risk Profile, Good Corporate Governance, Earning, dan Capital dalam Memprediksi Financial Distress pada Bank Umum Syariah di Indonesia. JAE (JURNAL AKUNTANSI D AN EKONOMI), 5(2), 100-111. 